\title{
ПРАВОВА ПРИРОДА ІНСТИТУТУ ГРУПОВОГО ПОЗОВУ В ЦИВІЛЬНОМУ СУДОЧИНСТВІ
}

Постановка проблеми. Мета судової реформи - це насамперед ефективне, доступне та справедливе судочинство, яке буде здійснюватися своєчасно, з реалізацією принципів цивільного процесуального права, у певному процесуальному порядку, з дотриманням цивільної процесуальної форми, що в майбутньому і призведе до ухвалення законного та обгрунтованого рішення, виконання якого свідчитиме, що невизнані, оспорювані, порушені права, свободи та інтереси громадян знайшли свій судовий захист. Адже кожна особа, права якої порушені, має право на звернення до суду за захистом своїх прав (ст. 55 Конституції України) (далі - КУ) [1]. Однак, якщо йдеться про ефективне судочинство, то перш за все необхідно забезпечити дієві механізми задля його реалізації з дотриманням норм КУ, національного законодавства, законів України, міжнародних договорів. На наш погляд, одним з аспектів забезпечення ефективності та своєчасності судового захисту, розвантаження судової системи, є реалізація та впровадження інституту групових позовів у цивільному судочинстві, який спрямований на захист невизначеного кола осіб, права яких порушені.

Чинне цивільне процесуальне законодавство передбачає низку таких інститутів, які мають на меті забезпечити справедливе, неупереджене та своєчасне судочинство з метою захисту порушених, невизнаних або оспорюваних прав, свобод чи інтересів фізичних осіб, прав та інтересів юридичних осіб, інтересів держави, що в майбутньому сприятиме реалізації положень КУ, завдань цивільного судочинства (ст. 2 Цивільного процесуального кодексу України) (далі - ЦПК України) [2], норм іншого національного та міжнародного законодавства. Саме такими інститутами в чинному ЦПК України є інститут підсудності в цивільному судочинстві, процесуальні строки, заходи процесуального примусу, інститут співучасті в цивільному процесі, участь представника в судовому засіданні, об'єднання позовних вимог, спрощені види провадження та інші. Однак реалії сьогодення дають підстави стверджувати, що перелічені інститути та їх застосування не до кінця дають змогу вирішити проблеми теоретичного і практичного змісту, не встановлюють механізмів пред'явлення та вирішення однотипних спорів групи осіб, що і вимагає реформування процесуального законодавства, яке нині і відбулося. Хоча наше сьогодення показує, що з кожним днем зростає кількість випадків, де порушуються саме права, свободи та інтереси груп осіб. Це і зумовлює важливість дослідження особливостей захисту інтересів групи осіб та розробки відповідних пропозицій до законодавства.

Аналіз останніх досліджень і публікацій. У науці цивільного процесуального права питання групового позову досліджувались такими вітчизняними та зарубіжними науковцямитавченими-процесуалістами:В.К.Пучинським,Г.О.Аболоніним,Г.П.Тимчинком, В.В. Ярковим, Д.Д. Луспеником, Н.Ю. Сакарою, А.В. Губською, Т.В. Степаненко, В.В. Комаровим, С.Я. Фурсою, Ю.Ю. Трачем, С.С. Бичковою, В.А. Кройтором, В.І. Тертишніковим, Н.О. Чечіною, К.С. Юдельсоном, Ю.В. Білоусовим, 
Я.М. Романюком, Г.Л. Осокіною, О.П. Клейнманом та ін. Проте багатогранність інституту групового позову вимагає більш детального розгляду, наукового обгрунтування та вивчення, оскільки наразі немає комплексного, цілісного уявлення про запровадження в Україні такого виду позовів та механізму його реалізації відповідно до міжнародних стандартів та зарубіжного досвіду.

Метою статті $€$ дослідження та аналіз правової природи інституту групового позову в цивільному судочинстві.

Виклад основного матеріалу. Які ж фактори сприяють збільшенню актуальності захисту прав та інтересів групи осіб? На нашу думку, це, по-перше, розвиток економіки та економічних відносин; поява нових інститутів; ускладнення економіки та соціальних процесів; виникнення нових форм підприємницької діяльності; екологічні правопорушення; порушення прав споживачів; відносини у сфері банківської діяльності; стихійні лиха; фінансові операції та ринок цінних паперів; по-друге, збільшення кількості спорів за позовами з виплати заробітної плати, про нарахування та перерахунок пенсій та різних видів допомоги (по безробіттю, догляду за дитиною, субсидій), спорів з релігійних питань (відмова від паспорта, ідентифікаційного коду), спорів 3 особами, які постраждали внаслідок Чорнобильської катастрофи, проведення Антитерористичної операції на Сході України, позови військовослужбовців та дітей війни тощо. Так, Глибоиьким районним судом Чернівещької області розглядалась иивільна справа за позовною заявою ОСОБА_1, ОСОБА_2, ОСОБА_3, ОСОБА_4 доОСОБА_5 селищної ради Чернівещької області про визнання права власності на спадкове майно за законом (справа № 715/111/19). Інший приклад. Новоселеиьким районнил судом Чернівецької області розглядалась иивільна справа за позовом ОСОБА_2, ОСОБА_3 та ОСОБА_4 до Новоселииької міської ради об’єднаної територіальної громади про визнання права власності на спадкове майно (справа № 720/2143/18).

Все це дає підстави стверджувати про необхідність вивчення та з'ясування правової природи інституту групового позову і запровадження його в національну практику як інституту, що спрямований на захист групи осіб.

Генеза становлення інституту групового позову починається з середини XVI ст. із судової практики англійських судів справедливості, а пізніше цей вид позовів був позитивно сприйнятий у США. Вказана форма захисту характерна і для багатьох країн Європи, таких як: Німеччина, Франція, Іспанія, Італія, Португалія, Люксембург, Швеція, Данія, Польща, Литва та ін. Так, на думку Б. Маана, судова реальність як у Європі, так і в США та Канаді виявила, що такий додатковий процесуальний механізм корисний для належного захисту законних інтересів споживачів або груп людей, які зазнали значних збитків [3, с. 13]. Тому вивчення світового досвіду має стати передумовою для активізації в Україні групових позовів як судового механізму захисту прав фізичних осіб, юридичних осіб, держави. На жаль, вітчизняне законодавство не містить процедури вирішення спорів за такими однотипними позовами невизначеного кола осіб. У вітчизняній системі права відсутня реально діюча судова форма захисту групових інтересів. Чинне законодавство не визначає поняття і порядку застосування групових позовів, а обмежується двома нормами закону. Нині в Україні трапляється застосування групового позову, зокрема, в Законі України «Про захист прав споживачів» від 12 травня 1991 року № 1023-XII, який передбачає право об’єднань споживачів 
звертатись з позовом до суду про захист прав споживачів. Підтвердженням цього є ч. 1 п. 6 ст. 161 ЦПК України, де законодавець вказує на вимогу, за якою може бути видано судовий наказ у спрощеному порядку, зокрема заявлено вимогу про повернення вартості товару неналежної якості, якщо є рішення суду, яке набрало законної сили, про встановлення факту продажу товару неналежної якості, ухвалене на користь невизначеного кола споживачів.

На доцільності запровадження в Україні інституту групового позову акцентував увагу Я.М. Романюк, який переконував, що запровадження інституту групового позову є раціональним як з точки зору інтересів осіб, права яких порушено, гарантуючи справедливість задоволення однотипних вимог рівною мірою, так і судів, забезпечуючи необхідну процесуальну економію, що сприятиме зниженню навантаження на суди [4, с. 304]. Тому в науці цивільного процесу це питання вже тривалий час привертає значну увагу науковців. Аналіз доктринальних положень такого інституту призвів до виокремлення декількох напрямів щодо поняття та сутності групових позовів.

Представник першого напряму Я.Г. Вафін вважає, що груповий позов - це позов, у разі звернення з яким представник групи може вимагати судового захисту прав та інтересів усіх інших осіб, яким заподіяно шкоду одним правопорушником [5]. А. Жиді розкриває груповий позов як позов, який подається груповим позивачем (або колективним утворенням) з метою захисту права, яке належить групі осіб, рішення за яким буде пов’язувати всю групу повністю (res judicata) [6, с. 153]. За твердженням Г.О. Аболоніна, груповий позов - це звернення, яке реалізується від імені групи осіб щодо розгляду спору, який виник на підставі спільного юридичного факту, або є вимогою про поновлення порушеного права, зміну статусу певних юридичних та фізичних осіб, яке заявляється в інтересах усіх членів групи на підставі адекватного представництва [7, с. 10]. Б.О. ЖЖурбін указує, що груповий позов є вимогою про захист порушених суб'єктивних прав як учасників численної групи осіб, так і інтересів суб'єкта, який звернувся до суду за захистом цієї групи [8, с. 9]. Американський вчений В. Бернам розглядає груповий позов як позов одного або декількох представників певної групи людей зі спільними позовними вимогами, які виступають від імені всієї групи [9, с. 393].

Як бачимо, науковці цього напряму, розкриваючи поняття та сутність групового позову, розуміють під ним спільну вимогу, яка заявляється на захист групи осіб однією особою чи кількома особами з метою захисту порушених, невизнаних або оспорюваних прав, свобод чи інтересів фізичних осіб, прав та інтересів юридичних осіб, інтересів держави.

У науці цивільного процесуального права серед науковців сформувався ще й інший підхід до розуміння групового позову, зокрема, щодо ототожнення його з такими категоріями, як «процесуальна співучасть» та «процесуальне представництво». Підтвердженням існування цього підходу є науковий доробок таких учених, як В.А. Миколаєць, яка вважає, що за своєю юридичною природою груповий позов можна вважати активною процесуальною співучастю з усіма встановленими процесуальним законом ознаками цього інституту [10, с. 40]. К. Осакве особливою процедурою процесуальної співучасті називає груповий позов, що призначений для об'єднання однорідних вимог вельми численної групи співпозивачів, що дає змогу представнику (або представникам) такої групи, який визвався самостійно діяти без доручення всіх інших 
співпозивачів та дії якого інспіруються самовизваним адвокатом усіх співпозивачів, пред'явити об'єднаний позов від імені всіх співпозивачів, які входять у таку групу [11]. Стверджувальну позицію знаходимо у праці Н.С. Батаєвої, яка ототожнює груповий позов з процесуальною співучастю, називаючи його підвидом процесуальної співучасті [12, с. 41$]$.

Серед прихильників такого підходу є науковці, які вважають групові позови своєрідним «гібридом» співучасті та представництва [13, с. 476]. Це випливає із твердження В.К. Пучинського, який, досліджуючи правову природу похідного (представницького) позову в Англії, зазначив, що цей інститут є свого роду поєднанням таких правових категорій, як процесуальна співучасть та представництво, суть якого зведена до наявності у групи суб'єктів єдиного інтересу, порушення цього інтересу, можливості захисту кожного тим рішенням, яке витребовують у суду представники цієї групи, які розпочали процес [14]. Аналогічну позицію знаходимо у П.П. Колесова, який вважає, що груповий позов $є$ поєднанням інститутів судового представництва та процесуальної співучасті [15, с. 13-28].

На наш погляд, перелічені позиції вчених заслуговують на увагу, оскільки справді, якщо проаналізувати вказані інститути, знаходимо у їх співвідношенні деякі спільні риси. Зокрема, якщо зазначити визначення процесуальної співучасті, то класичним залишається розуміння іï як множинності осіб на боці позивача і відповідача. Така множинність притаманна й інституту групового позову. Участь у справі кількох позивачів і (або) відповідачів допускається, якщо: предметом спору є спільні права чи обов'язки кількох позивачів або відповідачів; права та обов'язки кількох позивачів чи відповідачів виникли з однієї підстави; предметом спору є однорідні права і обов'язки (ст. 50 ЦПК України). У науці цивільного процесуального права вчений-процесуаліст М.М. Ясинок за підставами виникнення виділяє обов'язкову та факультативну співучасть. Обов'язкова - співучасть, яка виникає за спільності прав та обов'язків кількох осіб, що виникають у матеріально-правових відносинах, а вирішення справи неможливе без залучення інших співпозивачів та співвідповідачів. Тоді як необов'язкова - співучасть, де розгляд справи за позовними вимогами може бути здійснений як у самостійних провадженнях (шляхом роз'єднання позовних вимог), так і в одному (шляхом об’єднання позовних вимог) [16, с. 325]. Отже, така ознака, як множинність осіб, є спільною для обох інститутів. Проте наявність спільної ознаки не дає ще підстав ототожнювати ці поняття. Вирішальну крапку можна поставити, лише виявивши низку відмінних рис між цими інститутами. Так, А.В. Губська першу відмінність вбачає в індивідуалізації учасників процесу. Пояснюючи це тим, що якщо для процесуальної співучасті є обов'язковою ідентифікація суб'єктів процесу, то для групового позову виокремлення учасників цивільних процесуальних правовідносин не є обов'язковим. Другу відмінність автор вбачає в особистій участі у розгляді справи, пояснюючи це тим, що у процесуальній співучасті кожний зі співпозивачів - сторона у справі. Тоді як у груповому позові вся група - сторона у справі. Спрямованість захисту є третьою відмінною рисою співучасті і групового позову. Співучасті притаманна спрямованість на захист власних інтересів від імені співучасника, натомість за умови групового позову забезпечується захист інтересів усієї групи від імені заявника позову [17, с.70]. Ми підтримуємо проаналізовану точку зору А.В. Губської і стверджуємо, що ці поняття $е$ 
окремими процесуальними інститутами. Груповий позов є самостійним інститутом у цивільному процесі та наділяється ознаками, які дають підстави вважати його незалежність, а саме: невизначеність кількісного складу групи, її мінливість; неможливість застосування факультативної співучасті, позаяк його можна розглядати лише в аспекті обов’ язкової співучасті; стороною (позивачем) у справі є вся група; не потрібним є визначення кількісного складу численної групи осіб на стадії пред'явлення позову; захищаються права всієї групи, а не окремо кожного учасника процесу та ін.

Як нами зазначалося вище, не тільки із процесуальною співучастю, але і з процесуальним представництвом ототожнюють інститут групового позову у науці цивільного процесуального права. Так, корифей у науці цивільного процесуального права В.В. Комаров дає визначення процесуального представництва, під яким розуміє правовідношення, на підставі якого одна особа сприяє захисту прав, свобод та інтересів іншої особи та (або) здійснює від іï імені процесуальні дії в межах наданих повноважень [18, с. 341]. Як вважає вітчизняний учений-процесуаліст С.Я. Фурса, правовими особливостями представника у цивільному процесі є завдання і мета участі останнього під час здійснення правосуддя у цивільних справах [19, с. 196]. Така правова позиція науковців дає змогу стверджувати, що інститут процесуального представництва теж суттєво відрізняється від інституту групового позову. Не заперечуємо, цим двом поняттям притаманна спільна риса - участь представника у суді, який представляє та захищає права, свободи та інтереси інших осіб. Проте процесуальний представник, діючи на підставі документів, що посвідчують його повноваження під час розгляду справи, захищає не власний (особистий) інтерес, а інтерес особи, тоді як у груповому позові заявник (ініціатор) захищає свій матеріальний і процесуальний інтерес та діє від імені всієї групи без її попереднього або подальшого доручення. Також цивільні процесуальні відносини, які виникають між представником та судом, а також ті, що виникають у разі пред’явлення групового позову, носять різний характер та мають різну правову природу, що і зумовлює нас зробити висновок про самостійність та автономність цих зазначених понять.

Третій напрям створили вчені, які визначають груповий позов як своєрідну процесуальну конструкцію (форму, засіб тощо), наповненням якої є специфічний нормативно-правовий механізм, який являє собою особливі правила, доповнення та винятки із загального порядку розгляду цивільних справ у порядку позовного провадження. Прихильником цього напряму є Ю.Ю. Трач, який зауважує, що груповий позов це не просто множинність осіб у цивільній справі, а особливий вид позовного провадження, що регулює пред’явлення, розгляд, вирішення та виконання вимог значної кількості осіб [20]. Ш.Б. Кулахметов розуміє, що груповий позов є вимогою групи осіб - учасників одного типового матеріального правовідношення, яке спрямоване на захист суб'єктивних прав та законних інтересів кожного учасника групи, шляхом застосування процесуальної форми розгляду справи з одночасною участю у процесі групи осіб та особи-представника [21, с. 8]. За твердженням Д.Я. Малєшина, груповий позов доцільно розглядати як процесуальний інститут, який дає змогу одній або декільком особам подати позов на захист прав групи осіб або невизначеного кола осіб без обов’язкової їх участі у процесі. Автор підкреслює, що основною особливістю такого процесуального інституту є те, що судове рішення обов’язкове не тільки для учасни- 
ків судового провадження, а й для тих суб’єктів, що безпосередньо не брали участі у такому судовому провадженні, та, можливо, навіть і не знали про його наявність. При цьому він додає, що жодний із членів групи не має переваг у разі стягнення з боржника коштів, усі мають рівні права та користуються рівними обов'язками [22, с. 71].

Отже, як бачимо, прихильники проаналізованого напряму для характеристики групового позову звертають увагу на визначення групового позову як процесуального прийому (засобу) пред'явлення вимог у суді, процесуальний порядок порушення справи груповим позовом у суді від імені групи осіб з вимогами, що спрямовані до одного і того ж відповідача у межах одного провадження.

Заслуговуе на увагу й існування четвертого напряму, прихильники якого взагалі не визнають доцільності існування такого інституту, як груповий позов. Представник російської школи С.А. Іванова доводить, що ідея виділення групового позову як самостійного виду позовів не має належного наукового обгрунтування [23, с. 235]. Одностайної позиції дотримується і Т.В. Сахнова, яка стверджує, що натепер відсутні процесуальні підстави для виділення групових позовів у самостійний вид позовів [24, с. 311]. Категоричною в цьому є і Т.Ю. Карева, оскільки вважає, що модель групового позову $€$ надуманою, складною, яка потребує тривалих строків розгляду. Цивільне процесуальне законодавство містить досить засобів для одночасного розгляду численних вимог приватноправового характеру (представництво, об’єднання позовних вимог, інститут процесуальної співучасті). Свою позицію автор доводить і тим, що у західних країнах також неоднозначно ставляться до інституту групового позову [25, с. 167].

На жаль, ми не можемо погодитись із проаналізованими вище думками вчених, адже такі інститути цивільного процесу, як процесуальна співучасть, представництво та ін., не можуть собою замінити інституту групового позову, який володіє окремими, притаманними йому ознаками, що і свідчить про самостійність цього поняття. Ю.Ю. Трач цілком правильно стверджує, що практика України та інших держав переконливо свідчить про недостатні можливості таких процесуальних інститутів, як співучасть та об'єднання справ в одне провадження для ефективного захисту інтересів групи осіб. Так, право державних та приватних організацій діяти від імені групи осіб непридатне для вирішення спорів майнового характеру, а захист інтересів осіб, право яких порушене, спеціальними організаціями викликає до життя складну проблему регулювання відносин між такими організаціями та окремими потерпілими, що виходять за межі процесуальних відносин та не підлягають процесуальному регулюванню. Водночас надання особливого преюдиційного значення «модельного» розгляду одній із кількох справ не узгоджується з принципом безпосередності судового розгляду [26, с. 102-103]. Власне, саме реалізація групових позовів та нормативне закріплення їх у законодавстві сприятимуть розвантаженню судової системи, яка завантажена подібними справами, що і призведе в майбутньому до виконання одного із завдань цивільного судочинства - своєчасного розгляду і вирішення цивільних справ, яке також закріплено і в інших національних та міжнародних положеннях. Значне навантаження однотипними справами, низка з яких інколи є досить очевидними і недоцільними для розгляду в самостійних провадженнях, стало поштовхом до вивчення питання про ймовірність і доцільність запровадження іноземного досвіду застосування інституту групового позову в процесуальному законодавстві України [27, с. 2]. 
Проаналізовані нами погляди вітчизняних та зарубіжних учених-процесуалістів дають нам змогу зробити висновок про наявність у науці цивільного процесуального права різних поглядів, думок, суджень стосовно інституту групового позову, що $\mathrm{i}$ зумовило існування декількох напрямів у визначенні цього поняття. Однак для того, щоб краще з'ясувати сутність та специфіку групового позову, слід, на наш погляд, проаналізувати ознаки, що йому притаманні.

Насамперед слід виділити таку ознаку групового позову, як його універсальність . Цей механізм може бути застосований як результативний спосіб захисту будь-яких суспільних відносин, де виникають конфлікти, які зачіпають права, свободи та законні інтереси численних груп осіб, не обмежуючись при цьому рамками однієї галузі права [28]. Тобто механізм групового позову поширюється не тільки на цивільно-процесуальні правовідносини, а на широке коло правовідносин, що виходять за межі цивільного процесуального права.

Численність та невизначеність персонального складу учасників групи на стороні - ще одна ознака групового позову, яку Т.В. Олдак пропонує розглядати у «широкому розумінні»: як групу, що об’єднує у собі всіх потенційних носіїв порушених прав та законних інтересів осіб, на захист яких подається груповий позов, безпосередня участь у судовому процесі яких $€$ практично неможливою, а з іншого - необхідність наявності певної мінімальної кількості учасників [28]. При цьому зарубіжний досвід закріплює різні підходи стосовно визначення кількості осіб у разі звернення до суду. Так, наприклад, у Російській Федерації визначено, що до подання позовної заяви до суду до неї має приєднатись не менш як п’ять осіб, в Австралії - не менш як сім осіб, канадське процесуальне законодавство передбачає наявність двох і більше позивачів [29, с. 303]. Наведене свідчить про необхідність закріплення в національному законодавстві не тільки самої процедури пред'явлення групових позовів, але й уточнення чіткої мінімальної кількості суб'єктів звернення як однієї з передумов пред’явлення таких позовів, наприклад, не менше трьох учасників.

Єәність способу захисту всіх вимог осіб, інтереси яких захищаються груповим позовом, є наступною ознакою цього виду позовів. Характеризуючи вказану ознаку, Т.В. Олдак зазначає, що як і особа, яка ініціює процес, так і учасники, які приєднались до групи, мають використовувати єдиний спосіб захисту цивільних прав та інтересів, передбачений статтею 16 ЦК України. Також автор додає, що непідтримання одним з потенційних носіїв порушеного, невизнаного або оспорюваного права, обраного способу захисту суб'єктами, що беруть участь у груповому позові, ставить такого суб'єкта перед дилемою: чи приєднатись до групового позову, чи здійснювати захист власних прав та інтересів за допомогою «індивідуальної» позовної заяви [28].

Наступна ознака, на яку звертає увагу В.А. Миколаєць, - співпадіння фактичних i правових підстав групового позову [30, с. 148]. Сутність такої ознаки розкривається через визначення двох взаємопов'язаних складових частин, які необхідно розглядати спільно, в сукупності, адже наявність лише однієї з них не дає можливості говорити про порушення прав та законних інтересів численної групи осіб. Так, фактичний критерій вказує на ідентичність обставин, що стали спільними і в яких опинилась численна (невизначена) група осіб, чиї права та законні інтереси порушуються, вказуючи на певний юридичний факт. Тоді як юридичний критерій говорить про спільну правову 
природу порушених, невизнаних або оспорюваних прав та законних інтересів численної (невизначеної) групи осіб.

Наявність однієї спільної для усіх позивачів сторони з протилежнили інтересали - відповідача, який у разі звернення позивача до суду вважається ймовірним суб'єктом порушення, невизнання чи оспорювання прав, свобод та інтересів іншої особи. Адже сторони, порушуючи процес, є можливими суб’єктами спірних матеріальних правовідносин. Нерідко на практиці виникають підстави заміни неналежного відповідача у процесі чи постановлення суддею ухвали про відмову у задоволенні позовних вимог позивачеві, якщо виявиться, що позов пред’явлено не до тієї особи, яка має відповідати за ним.

Особливий суб'єктний склад провадження за груповим позовом та наявність різних за обсягол процесуальних прав і обов'язків в учасників такого провадження ще одна ознака групового позову. Особа (позивач-представник), яка є ініціатором процесу, є членом численної (невизначеної) групи осіб і виступає від її імені. Судовий розгляд справи за груповим позовом ініціюється цією особою (позивачем-представником) у результаті порушення прав та інтересів цієї особи та групи осіб. Така особа наділяється загальними та спеціальними процесуальними правами та обов'язками позивача у процесі, які закріплені в ст. 43, 49 ЦПК України. Стосовно осіб, права яких порушені і які приєдналися до групового позову, М.В. Степанчук зазначає, що вказані особи мають у справі матеріальний і процесуальний інтерес, оскільки сам факт належності таких осіб до групи свідчить про те, що вони є такими ж носіями порушеного права, як і особа, що виступає від імені групи осіб (позивач-представник). Однак такі особи (члени групи осіб) зазвичай наділяються дещо звуженими процесуальними правами та обов'язками, на відміну від особи, що ініціює груповий позов (позивач-представник) [31, с. 1690].

3 цієї ознаки випливає зміст наступної, що також стосується прав та інтересів учасників справи. Зокрема, позивач, який звертається до суду, пред’являючи груповий позов і діючи в процесі на всіх стадіях розгляду та вирішення справи, захищає не лише власні, особисті права, свободи та інтереси, але і права та законні інтереси групи осіб. Більше того, як нами описувалося вище, у співвідношенні групового позову з інститутом представництва позивач-представник діє без спеціальної довіреності від учасників групи осіб, що, безумовно, спрощує процес захисту прав та інтересів численної (невизначеної) групи осіб та вкотре відрізняє ці два самостійні інститути в теорії та практиці застосування.

Тотожність предмета доказування стосовно фактів, що обгрунтовуються учасникали групи, науковцями розглядається як окрема ознака групового позову. Щодо цієї ознаки заслуговує на увагу позиція В.А. Миколаєць, яка стверджує, що предмет доказування у справах за груповими позовами можна умовно поділити на дві частини: обгрунтованість вимоги групи та належність вимоги кожному з учасників групи. Питання обгрунтованості вимоги групи має спільний характер і полягає у тому, наскільки доведеною є узагальнена вимога цієї групи до цього відповідача. Належність вимоги кожному з учасників групи вказує на доведеність правомірності включення кожної окремої особи до групи [32, с. 10-11]. Отже, предмет доказування у справах за груповим позовом вміщує в собі сукупність двох взаємопов' язаних частин загальної та індивідуальної. 
Не менш важливою є обов'язковість судового рішення за груповим позовом для всіх членів численного (невизначеного) кола осіб: для осіб, які безпосередньо брали участь у судовому процесі, і для учасників групи, які такої участі не брали. Судове рішення, ухвалене на користь групи осіб, має свої особливості не тільки щодо процедури його ухвалення, але і щодо змісту та механізму реалізації. Так, кожен член такої групи індивідуалізується, а тому відповідач буде нести окремо стосовно кожного учасника якісь певні обов'язки у разі ухвалення рішення на користь позивачів у процесі. Рішення суду, ухвалене за результатами розгляду групового позову, матиме персоніфікований характер, оскільки група, яка на момент пред’явлення і подачі групового позову була невизначеною, персоніфікується. Окрім того, одна з ознак, яка пред’являється до судового рішення, - це преюдиційність, яка полягає в тому, що встановлені рішенням суду в тій чи іншій справі факти і правовідносини є обов'язковими під час розгляду інших цивільних справ, в яких беруть участь ті ж самі особи. Вказана ознака знайшла своє нормативне закріплення в ч. 3-6 ст. 82 ЦПК України зокрема.

Однією з ознак групового позову є иивільна процесуальна форла їх пред’явлення. Як відомо, процесуальна діяльність суду спрямована на виконання завдань цивільного судочинства шляхом розгляду та вирішення цивільних справ у порядку цивільного судочинства, що виникають із цивільних, земельних, трудових, сімейних, житлових та інших правовідносин ч. 1 ст. 19 ЦПК України. Процесуальна діяльність учасників судового процесу спрямована на здійснення належних їм процесуальних прав і обов’язків з метою виконання своїх функцій у цивільному процесі. Характерним для діяльності суду і учасників справи є те, що така діяльність здійснюється в чітко визначеній процесуальній формі, найважливішою особливістю якої є обов’ язковість її дотримання. Будь-яка діяльність не може бути здійснена без певного процесуального порядку, певної послідовності вчинення судом та учасниками процесу процесуальних дій і фіксування цих дій у процесуальних документах. Таким порядком і служить цивільна процесуальна форма, яка є тією основою, базисом, на якому будується цивільне судочинство в цілому [33, с. 48-49]. Оскільки цивільна процесуальна форма є характеристикою процесуальної діяльності, то зміст її становлять сукупність правил і вимог, що визначають порядок здійснення правосуддя з цивільних справ. Звідси цілком виправданим є детальне закріплення в чинному процесуальному законодавстві процесуального порядку пред’явлення, механізму реалізації та судового розгляду групових позовів з дотриманням цивільної процесуальної форми, що забезпечить якісне впровадження та застосування цього інституту на національному рівні в Україні.

На підставі проаналізованих наукових підходів щодо поняття групового позову, виокремлення його ознак доцільно сформулювати значення групового позову, яке полягає в тому, що вони сприятимуть: захисту значного кола осіб, права та інтереси яких порушені; зменшенню навантаження на суди малозначними позовами, однотипними зверненнями громадян; економії часу та процесуальних засобів учасників процесу; економії коштів громадян та держави; концентрації доказового матеріалу; недопущенню ухвалення різних судових рішень; підвищенню ефективності роботи судів; розширенню доступу до правосуддя; забезпеченню ефективності й оперативності правосуддя; забезпеченню єдності судової практики; уникненню розбіжностей у судовій практиці у разі розгляду ідентичних справ різними судами; позитивному впливу на 
поведінку учасників процесу; реалізації захисту публічно-правового та індивідуального інтересу тощо.

Аналіз теоретичних підходів до визначення групового позову, характеристика притаманних ознак та його значення для цивільного судочинства сприяло формуванню авторського визначення процесуального механізму захисту численної групи осіб, права яких порушені чи не визнаються. Так, груповий позов - це позов, який пред'являється до суду на захист групи осіб (невизначеного кола осіб), права, свободи та інтереси яких порушені, якому притаманні ознаки, які відрізняють його від інших інститутів у цивільному судочинстві, який спрямований на забезпечення ефективності та доступності правосуддя, реалізація якого має відбуватись з дотриманням цивільної процесуальної форми.

Висновки. Отже, незважаючи на неабиякі проблеми запровадження того чи іншого інституту, ефективність саме групового позову вже доведена багатьма країнами як загального, так і континентального права. Тому досвід цих країн має сприяти становленню цього інституту і в Україні. Оскільки він є дієвим механізмом для розвантаження судової системи шляхом спрощення процесу звернення до суду. Звичайно ж, не слід забувати, що імплементація будь-якого нововведення вимагає часу, чіткості та послідовності зважених дій. Насамперед це - розробка нормативно-правових засад, які мають узгоджуватись із фундаментальними принципами, що закріплені в КУ, процесуальними нормами чинного законодавства, міжнародними договорами; впровадження чіткої процедури та умов, які б сприяли їх застосуванню. Тільки врахування всіх перелічених вище «постулатів» сприятиме ефективності цивільного судочинства, слугуватиме запорукою дієвого захисту порушених, невизнаних або оспорюваних прав, свобод та інтересів громадян.

\section{Jimepamypa}

1. Конституція України від 28 червня 1996 р. Відомості Верховної Ради України. 1996. № 30. Ст. 141.

2. Цивільний процесуальний кодекс України : чинне законодавство зі змінами та допов. станом на 1 лют. 2019 р. : (офіц. текст). Київ : ПАЛИВОДА А.В., 2019. 288 с. (Кодекси України).

3. Маан Б. Колективні позови в Європі. Право України. 2015. № 9. С. 13-17.

4. Романюк Я. Актуальні питання реформування цивільного процесуального законодавства України. Право України. 2012. № 8. С. 288-305.

5. Вафин Я. Особенности судопроизводства по групповым искам в Англии. URL: http://www.juristlib.ru/book_5459.html.

6. Жиди А. Кодекс гражданского судопроизводства: модель для стран континентального права. Закон. 2013. № 11. С. 151-163.

7. Аболонин Г.О. Групповые иски в гражданском процессе: автореф. дис. ... на соискание учен. степени канд. юрид. наук : спец. 12.00.15 «Гражданский процесс, арбитражный процесс». Екатеринбург, 1999. 28 с.

8. Журбин Б.А. Процессуальные особенности рассмотрения судами дел по групповым и производным искам : автореф. дис. ...на соискание учен. степени канд. юрид. наук : спец. 12.00 .15 «Гражданский процесс, арбитражный процесс». Саратов, 2009. 25 с.

9. Бернам У. Правовая система США. 3-й выпуск. Москва : Новая юстиция, 2006. 608 с.

10. Миколаец В. Понятие и признаки группового иска. Legea si viata. 2014. № 5/3. С. 38-41.

11. Осакве К. Классовый иск (class action) в современном американском гражданском процессе. Журнал российского права. 2003. № 3. URL: http://uristy.ucoz.ru/publ/11-1-0-397.

12. Батаева Н.С. Судебная защита прав и интересов неопределённого круга лиц : дис. ... канд. юрид. наук : спец. 12.00 .03 «Гражданское право; семейное право; гражданский процесс; международное частное право». Москва, 1998. $164 \mathrm{c.}$ 
13. Елисеев Н.Г. Гражданское процессуальное право зарубежных стран : учебник. 2-е изд., перераб. и доп. Москва : Проспект, 2004. 624 с.

14. Пучинский В.К. Гражданский процесс зарубежных стран / под. ред. В.В. Безбаха. Москва : Зерцало, 2008. 520 с. URL: http://mybrary.ru/users/personal/read/grajdanskiy-protsess-zarubejnyihstran.

15. Колесов П.П. Групповые иски в США. Москва : ООО «Городец-издат», 2004. 112 с.

16. Цивільний процес України : підручник / за заг. ред. д. ю. н., доцента М.М. Ясинка. Київ : Алерта, 2014. 744 c.

17. Губська А.В. Груповий позов: теоретико-правові підходи до визначення поняття. Порівнялььоаналітичне право. 2014. № 5. С. 68-72.

18. Курс цивільного процесу : підручник / В.В. Комаров, В.А. Бігун, В.В. Баранкова та ін.; за ред. В.В. Комарова. Харків : Право, 2011. 1352 с.

19. Цивільний процес України : академічний курс : підручник для студентів юридичних спеціальностей вищих навчальних закладів / за ред. С.Я. Фурси. Київ : Видавець Фурса С.Я. : КНТ, 2009. 848 с.

20. Трач Ю.Ю. Окремі аспекти відмінності групового позову та процесуальної співучасті. URL: http://www.lex-line.com.ua/?language=ru\&go=full_article\&id=392.

21. Кулахметов Ш. Особенности рассмотрения арбитражными судами дел о защите прав и законных интересов группы лиц : автореф. дис. ... канд. юрид. Наук : спец. 12.00.15 «Гражданский процесс, арбитражный процесс». Саратов, 2011. 24 с.

22. Малешин Д.Я. Российская модель группового иска. Вестник Высшего Арбитражного Суда Российской Федеращии. 2010. №. 4. С. 70-87.

23. Гражданский процесс : учебник / под ред. М.К. Треушникова. 2-е изд., перераб. и доп. Москва : Городец, 2007. 784 с.

24. Сахнова Т.В. Курс гражданского процесса: теоретические начала и основные институты. Москва : Волтер Клувер, 2008. 696 с.

25. Карева Т.Ю. Иски в защиту неопределённого круга лиц. Правоведение. 2008. № 4. С. 163-171.

26. Трач Ю.Ю. Передумови формування інституту групового позову в цивільному процесі України. Судова апеляиія. 2009. № 1 (14). С. 98-103.

27. Романюк Я.М., Майстренко Л.О. Масовий позов: загальні характеристики, зарубіжний досвід, перспективи впровадження в Україні. Вісник Верховного Суду України. 2015. № 3. С. 35-47.

28. Олдак Т.В. Специфіка групового позову у цивільно-процесуальному законодавстві України. Науково-практична Інтернет-конферениія 25.02.2016. Секція № 3. С. 1/3.

29. Білоусов Ю.В. Груповий позов: зарубіжний досвід та перспективи його використання в Україні. Університетські наукові записки. Часопис Хмельнииького інституту управління і права. $2012 \mathrm{p}$. вип. І. № 1 (41). С. 295-309.

30. Миколаєць В.А. Місце групових позовів у системі масових позовів. Митна справа. 2014. № 2 (92). Частина 2. Книга 2. С. 45-149.

31. Степанчук М.В. Решение арбитражного суда по групповому иску: практические проблеми реализации права на судебную защиту. Актуальные проблеми российского права. 2014. № 8 (45). C. $1689-1693$.

32. Миколаєць В.А. Груповий позов у цивільному процесі України : автор. дис. ... канд. юрид. наук : 12.00 .03 . Київ, 2014.20 с.

33. Татулич І.Ю. Цивільна процесуальна форма в суді першої інстанції в Україні : монографія. Чернівці. Чернівецький нац. ун-т, 2016. 192 с.

\section{Анотація}

Tатулич I. Ю. Правова природа інституту групового позову в цивільному судочинстві. - Стаття.

У статті викладено наявні в теорії цивільного процесуального права погляди науковців та вчених-процесуалістів як вітчизняних, так і зарубіжних на поняття інституту групового позову. 3'ясовано сутність та значення групового позову для цивільного судочинства. Охарактеризовано ознаки групового позову та на підставі цього сформульовано авторське визначення такого інституту.

Ключові слова: груповий позов, позивач, сторони, процесуальний порядок, правосуддя. 


\section{Аннотация}

Татулич И. Ю. Правовая природа института группового иска в гражданском процессе. - Статья. В статье изложены существующие в теории гражданского процессуального права взгляды отечественных и зарубежных учёных-процессуалистов относительно существующего понятия института группового иска. Определены сущность и значение гражданского иска в гражданском судопроизводстве. Дана характеристика существующих особенностей гражданского иска, на основании чего сформулировано авторское определение данного института.

Ключевые слова: групповой иск, истец, стороны, процессуальный порядок, правосудие.

\section{Summary}

Tatulych. I. Yu. Legal nature of the group lawsuit institution in civil proceedings. - Article.

The article outlines the existing theories of civil procedural law that are considered by scientists and procedural law researchers, both domestic and foreign ones, as to the concept of the group lawsuit institution. The essence and the significance of a group lawsuit for civil proceedings are found out. The features of a group lawsuit are characterized and on this basis the author's definition of this issue is formulated.

Key words: group lawsuit, plaintiff, parties, procedural order, justice. 